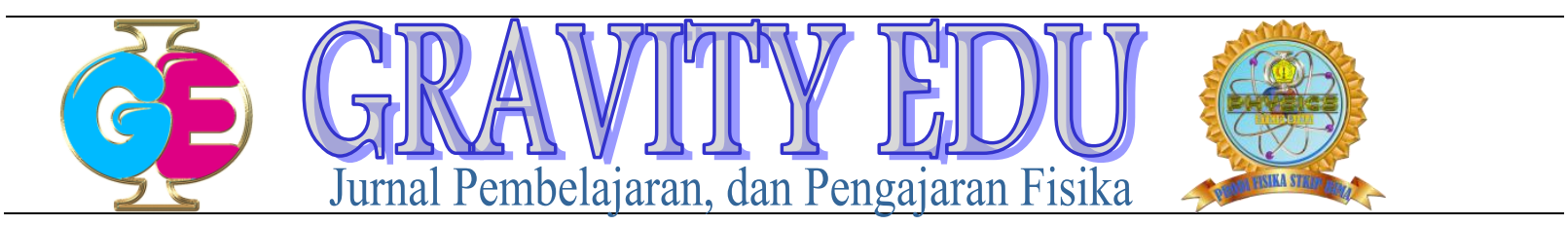

\title{
Efektivitas Virtual Laboratorium Berbantuan Software Proteus Pada Praktikum Fisika Rangkaian Listrik Terhadap Keterampilan Proses Sains Siswa
}

\author{
Lis Suswati ${ }^{1^{*}}$, M Subhan ${ }^{2}$, dan Kartini Wulandari ${ }^{3}$ \\ ${ }^{1,2}$ Program Studi Pendidikan Fisika STKIP Bima \\ ${ }^{3}$ SMA Negeri 5 Kota Bima \\ *E-mail : finayuli123@gmail.com
} d.hans2102@gmail@mail.com

\begin{abstract}
ABSTRAK : Penelitian ini bertujuan untuk mengetahui Efektivitas Virtual Laboratorium Berbantuan Software Proteus Pada Praktikum Fisika Rangkaian Listrik Terhadap Keterampilan Proses Sains. Jenis penelitian ini adalah Penelitian dengan pendekatan pre-experimental design yang dipilih adalah satu kelompok pretes-posttes (OneGroup Pretest-Posttest Design). Sampel dalam penelitian ini adalah siswa kelas XII MIA 1 SMA N 5 Kota Bima. Instrumen yang digunakan dalam penelitian ini adalah instrumen test, lembar observasi atau angket efektivitas. Data dianalisis menggunakan analisis persentase untuk keterampilan proses sains, uji N-gain dan uji t test Pairet. Hasil analisis data menunjukkan bahwa diperoleh bahwa dari 33 orang jumlah keseluruhan siswa mendapatkan nilai $\mathrm{N}$ - gain dengan kategori tinggi yaitu sebesar $67 \%$ atau 22 orang siswa, dan sebesar $33 \%$ atau 11 orang siswa mendapatkan penagruh kategori sedang. Uji Paired menunjukkan bahwa data yang diperoleh $t_{\text {hitung }}=18,206$ dibandingkan $t$ tabel $=2,036$. Kriteria pengujian $\mathrm{H}_{\mathrm{a}}$ diterima karena $\mathrm{t}_{\text {hitung }}>\mathrm{t}$ table. Dengan demikian dapat ditarik kesimpulan bahwa pemanfaatan virtual laboratorium berbantuan software proteus 8 professional efektif sebagai alternatif praktikum fisika rangkaian listrik.
\end{abstract}

Kata kunci: Virtual Laboratorium, Efektivitas Praktikum dan Keterampilan Proses sains

\section{ABSTRACT}

This study aims to determine the Effectiveness of Virtual Laboratory Assisted "Software-Proteus" In Electrical Circuit Physics Practicum Against Science Process Skills. The type of research used is the selected "pre-experimental design" approach chosen is (OneGroup Pretest-Posttest Design). The sample in this study was a grade XII MIA 1 SMA N 5 Kota Bima. The instruments used are test instruments, observation sheets or effectiveness questionnaires. The data was analyzed using percentage analysis for science process skills, $\mathrm{N}$-gain test and Pairet t-test. The results of the data analysis showed that from the total of 33 students get an $\mathrm{N}$-gain score with a high category of $67 \%$ or 22 students, and by $33 \%$ or 11 students get the medium category. Paired test shows that data obtained $t$-count $=18,206$ compared to $t$-table $=2,036$, Test criteria (Ha) are accepted because t-count $>t$-table. Thus, it can be concluded that the virtual utilization of softwareproteus assisted laboratories is very effective as an alternative to the practical physics of electrical circuit.

\section{PENDAHULUAN}

Fisika merupakan salah satu cabang ilmu dari sains, dan merupakan ilmu yang lahir dan berkembang lewat langkah-langkah pengamatan, perumusan masalah, penyusunan hipotesis, penguji hipotesis melalui eksperimen, penarikan kesimpulan, serta penemuan teori dan konsep. Fisika memuat banyak konsep secara umum terbagi menjadi dua yaitu terdiri dari fenomena material atau yang dapat diamati secara langsung dan fenomena yang abstrak atau yang tidak dapat diamati secara langsung, sehingga sebagian materi fisika tidak dapat dibayangkan begitu saja tanpa didampingi dengan praktikum yang dipelajari melalui pendekatan matematis dalam bentuk persamaan-persamaan. Salah satu materi Fisika yang tergolong cukup sulit dan abstrak yaitu materi tentang rangkaian listrik, karena hal ini memerlukan komponen-komponen listrik, hubungan antar komponennya, jalannya arus listrik, serta pembagian arus yang tidak dapat dilihat dan diamati langsung.

Untuk mencapai hal tersebut, salah satu penerapannya adalah kegiatan pembelajaran berbasis percobaan atau praktikum. Pemblajaran berbasis praktikum identik dengan kegiatan laboratorium yang merupakan tempat digunakan orang untuk menyiapkan sesuatu atau melakukan kegiatan ilmiah. [1]. Kegiatan praktikum merupakan salah satu kegiatan yang sangat berperan dalam meningkatkan keberhasilan proses belajar mengajar. Pembelajaran berbasis praktikum dapat digunakan sebagai alternative pembelajaran yang dapat mendorong siswa untuk belajar secara aktif 
merekonstruksi pemahaman konseptualnya [2]. Selain daripada itu kegiata laboratorium yaitu kegiatan pembelajaran melalui eksperimen, dimana penyajian pelajaran siswa melakukan percobaan dengan mengalami dan membuktikan sendiri sesuatu yang dipelajari dengan mengamati, manganalisis dan menarik kesimpulan sendiri tentang suatu objek yang diteliti tersebut [3]. Pembelajaran berbasis praktikum juga dapat membantu siswa melatih keterampilan sains pada sebuah konsep fisika yang rumit, siswa dapat terlatih melalui pengamatan, pengumpulan data, klasifikasi, berhipotesis menganalisis serta membuat kesimpulan sehingga siswa mampu membangun konsep sendiri berdasarkan penyelidakan dalam pemecahan masalah.

Keterampilan Proses Sains (KPS) didefinisikan sebagai keterampilan berpikir logis dan rasional yang digunakan dalam sains [4], yang dapat memaksimalkan keterlibatan aktif siswa dalam pembelajaran, membantu siswa memahami bagaimana kaidah dalam belajar yang seharusnya dilakukan secara permanen. KPS, baik dasar maupun terintegrasi dideskripsikan secara rinci seperti yang ditunjukkan oleh tabel berikut.

Tabel 1. Deskripsi Prilaku Keterampilan Proses Sains [5]

\begin{tabular}{|c|c|}
\hline KSP & Deskripsi \\
\hline Mengamati & $\begin{array}{l}\text { Proses untuk memperoleh informasi/data } \\
\text { menggunakan indera (mata, telinga, } \\
\text { hidung, kulit, lidah). }\end{array}$ \\
\hline Mengklasifikasikan & $\begin{array}{l}\text { Melakukan pengelompokan berdasarkan } \\
\text { karakteristik yang dimiliki suatu objek } \\
\text { (persamaan, perbedaan). }\end{array}$ \\
\hline $\begin{array}{l}\text { Melakukan } \\
\text { pengukuran }\end{array}$ & $\begin{array}{l}\text { Proses untuk memperoleh data suatu } \\
\text { benda/objek menggunakan alat ukur. }\end{array}$ \\
\hline Membuat prediksi & $\begin{array}{l}\text { Proses untuk menunjukkan } \\
\text { fenoema/kejadian yang akan terjadi } \\
\text { berdasarkan kejadian sebelumnya, atau } \\
\text { berdasarkan hasil pengamatan }\end{array}$ \\
\hline Membuat simpulan & $\begin{array}{l}\text { Memberikan penjelsan berdasarkan hasil } \\
\text { pengamatan }\end{array}$ \\
\hline Mengkomunikasikan & $\begin{array}{l}\text { Proses menyampaikan ide, pendapat, } \\
\text { baik lisan maupun tulisan secara jelas } \\
\text { dalam berbagai bentuk (tabel, grafik, } \\
\text { diagram, gambar) }\end{array}$ \\
\hline $\begin{array}{l}\text { Mendefinisikan secara } \\
\text { pperasional }\end{array}$ & $\begin{array}{l}\text { Membuat definisi operasional suatu } \\
\text { konsep atau variabel dengan } \\
\text { menunjukkan apa yang akan dilakukan, } \\
\text { dan bagimana melakukannya }\end{array}$ \\
\hline Mengontrol variable & $\begin{array}{l}\text { Mengidentifikasi variabel yang termasuk } \\
\text { variabel konstan, variabel manipulasi, } \\
\text { dan variabel respon }\end{array}$ \\
\hline Menyusun hipotesis & $\begin{array}{l}\text { Kemampuan untuk menyusun } \\
\text { pernyataan umum yang menjelaskan } \\
\text { terjadinya suatu fenomena, dan harus } \\
\text { dapat diuji. }\end{array}$ \\
\hline
\end{tabular}

Melakukan

eksperimen

Kegiatan ini merupakan kegiatan untuk menguji hipotesis. Kegiatan ini meliputi semua proses KPS.

Kegiatan pembelajaran praktikum masih dikatakan belum secara maksimal dilakukan terutama berkaitan dengan materi-materi seperti rangkaian kelistrikan hokum kirchoff, kenyataannya dibeberapa sekolah yang kekurangan perlengkapan laboratorium seperti daerah terpencil untuk melakukan kegiatan praktikum khususnya praktikum dalam rangkaian listrik tersebut tidak mudah dan tidak berjalan dengan baik. Kegiatan praktikum ini sering menemui hambatan seperti permasalahan waktu dan keterbatasan fasilitas yang dimiliki, seperti alat, dan bahan. Hambatan-hambatan tersebut menyebabkan kegiatan praktikum tidak berjalan dengan baik, bahkan kegiatan praktikum yang seharusnya dilakukan digantikan dengan kegiatan pembelajaran seperti biasa tanpa praktikum, biasanya tanpa praktikum pembelajaran fisika adalah pelajaran yang membosankan sehingga siswa tidak menguasai pelajaran dengan baik dan maksimal.

Salah satu cara untuk mengatasi masalah tersebut yaitu dengan dilakukannya praktikum virtual menggunakan virtual lab. Untuk melaksanakan praktikum tidak hanya melakukan eksperimen di dalam laboratorium, siswa juga dapat melakukannya pada virtual lab. Laboratorium virtual atau biasa disebut dengan istilah Virtual Lab adalah serangkaian alat, bahan, serta laboratorium berupa perangkat lunak (software) komputer, yang dioperasikan dengan komputer dan dapat mensimulasikan kegiatan di laboratorium seakan-akan pengguna berada pada laboratorium sebenarnya. Pembelajaran berbasis praktikum virtual dapat memberikan keleluasaan (fleksibility) terhadap waktu dan tempat dalam melakukannya dan hambatan lain seperti tidak tersedianya laboratorium dapat diatasi dengan kegiatan praktikum virtual. Virtual lab tentu tidak dapat digunakan untuk menggantikan kegiatan praktikum di dalam laboratorium yang sebenarnya, karena kegiatan praktikum dalam virtual lab tidak dapat melatih kemampuan proses siswa yang hanya akan didapat dari kegiatan praktikum di laboratorium sebenarnya, namun virtual lab ini dapat digunakan sebagai media pembelajaran yang dapat membantu siswa dalam memahami materi yang akan dipelajari [6].

Media virtual memungkinkan peserta didik bisa melakukan eksperimen untuk membuktikan suatu teori dengan mudah, jelas, dan tepat [7]. Pemanfaatan virtual lab pada materi fisika yang bersifat abstrak khususnya pada pokok bahasan rangkaian listrik, agar siswa seolaholah melakukan praktikum sebagaimana mestinya dan 
menguji keterampilan sains siswa, mengenal dan menggunakan media berbasis software yang dapat dimanfaatkan dalam pembelajaran. Sekarang banyak tersedia software yang dapat mensimulasikan materi pembelajaran dan difungsikan sebagai praktikum alternatif. Salah satu Software yang dapat digunakan sebagai media pembelajaran Virtual laboratorium adalah proteus 8 professional. Proteus 8 professional ini merupakan kelompok software simulasi elektronik yang digunakan untuk membantu pendidik dalam merancang dan mensimulasikan suatu rangkaian elektronik. Secara langsung software ini dapat digunakan pada materi rangkaian dengan kelengkapan komponen-komponen elektronik sehingga mengurangi kekurangan pada kelengkapan alat praktikum dalam laboratorium, dan software ini juga menjadi media pembelajaran pada laboratorium virtual tanpa menggunakan alat dari luar cukup menggunakan bantuan komputer atau laptop.

\section{METODE PENELITIAN}

Jenis penelitian ini adalah penelitian kuantitatif karena data penelitian berupa angka-angka dan analisis menggunakan statistik. Metod penelitian yang digunakan adalah penelitian eksperimen dengan pendekatan preexperimental design. Penelitian dengan pendekatan preexperimental design yang dipilih adalah satu kelompok pretes-posttes (OneGroup Pretest-Posttest Design). Dalam desain ini para subjek sebelum diberi perlakuan diberi pretes. Desain ini dapat digambarkan seperti pada tabel 1.

Tabel 1. Desain Eksperimen

\begin{tabular}{ccc}
\hline Pre Test & Treatment & Post Test \\
\hline $\mathrm{Y}_{1}$ & $\mathrm{X}_{1}$ \\
Keterangan: \\
$\mathrm{Y} 1 \quad$ : Pemberian tes sebelum materi diberikan \\
$\mathrm{Y} 2 \quad$ : Pemberian tes setelah materi selesai diberikan \\
$\mathrm{X} \quad$ : Treatment (dengan media software Proteus 8 \\
\multicolumn{2}{l}{ professional) }
\end{tabular}

Untuk mendapatkan data yang berkualitas, maka perlu digunakan instrumen penelitian yang benar-benar dapat mengukur efektivitas praktikum. Pengukuran efektivitas parktikum dalam penelitian ini berupa instrumen tes, lembar observasi dan angket atau kuisioner efektivitas. Data yang diperoleh dari instrumen maka akan dilakuka analisis diantara nya sebagai berikut :

1. Hasil Belajar

Untuk mengetahui hasil belajar, maka digunakan rumus sebagai berikut: $\%=\frac{\text { Jumlah skoryang diperoleh }}{\text { Jumlah skor total }} x$ skala maksimum

2. Keterampilan proses sains

Data keterampilan proses sains siswa diukur menggunakan lembar observasi dan dianalisis dengan menggunakan persentase kegiatan praktikum berlangsung. Untuk persentase digunakan rumus :

$\%=\frac{\text { Jumlah skor yang diperoleh }}{\text { Jumlah skor total }} x$ skala maksimum $(\%)$

[9]

Analisis keterampilan proses sains disajikan secara terperinci masing-masing indikator untuk melihat hasil yang jelas tiap indikator.

Tabel 2. Kategori Keterampilan Proses Sains (KPS)

\begin{tabular}{|l|l|}
\hline Skor & Kategori \\
\hline $81 \leq$ KPS $\leq 100$ & Sangat baik \\
\hline $61 \leq$ KPS $\leq 80$ & Baik \\
\hline $41 \leq$ KPS $\leq 60$ & Cukup \\
\hline $21 \leq$ KPS $\leq 40$ & Kurang \\
\hline $0 \leq$ KPS $\leq 20$ & Sangat kurang \\
\hline
\end{tabular}

Sedangkan untuk mengetahui kefektifan keterampilan proses sains penggunaan media pembelajaran praktikum dengan media proteus 8 profesional dianalisis menggunakan hasil pretest, posttes, gain dan $\mathrm{N}$-gain. Gain adalah selisih antara nilai pretest dan posttest. Untuk menunjukkan kualitas praktikum menggunakan media proteus 8 profesional peningkatan keterampilan proses sains digunakan rumus rata-rata gain ternormalisasi. $\mathrm{N}$-gain (normalized gain) digunakan untuk mengukur peningkatan keterampilan proses sains pretest dan posttest [10]. Rumus N-Gain seperti di bawah ini :

$$
\mathrm{N}-\text { Gain }=\frac{\text { skor posttest }- \text { skor preetest }}{\text { skor ideal }- \text { skor preetest }}
$$

Tabel 3. Kriteria Gain Ternormalisasi

\begin{tabular}{|l|l|}
\hline Nilai Gain Ternormalisasi & Interpretasi \\
\hline $\mathbf{0 , 7 0} \leq \mathbf{g} \leq \mathbf{1 0 0}$ & Tinggi \\
\hline $\mathbf{0 , 3 0} \leq \mathbf{g}<\mathbf{0 , 7 0}$ & Sedang \\
\hline $\mathbf{0 , 0 0}<\mathbf{g}<\mathbf{0 , 3 0}$ & Rendah \\
\hline $\mathbf{g}=\mathbf{0 , 0 0}$ & Tidak terjadi peningkatan \\
\hline
\end{tabular}

Untuk mengetahui ada dan tidak ada kefektifan perubahan secara signifikan setelah menggunakan media proteus 8 profesional maka dilakukan uji hipotesis. Uji hipotesis one group desain ini yang digunakan adalah uji hipotesis dependen test dengan menggunakan persamaan di bawah ini. 


$$
t=\frac{D}{\left(\frac{S D}{\sqrt{N}}\right)}
$$

Keterangan :

$\mathrm{t}=\mathrm{t}_{\text {-hitung }}$

$\mathrm{D}$ = rata-rata selisih 2 mean

$\mathrm{SD}=$ standart deviasi selisih perbedaan,

$\mathrm{N}=$ Jumlah Sample.

\section{[11]}

\section{HASIL DAN PEMBAHASAN}

Pembelajaran praktikum menggunakan media software proteus 8 profesional dilakukan setelah pemberian materi tentang rangkaian listrik dengan mengamati keterampilan sains siswa berdasarkan lembar observasi, hasil analisis data yang dihasilkan sebagai mana ditunjukka grafik berikut :

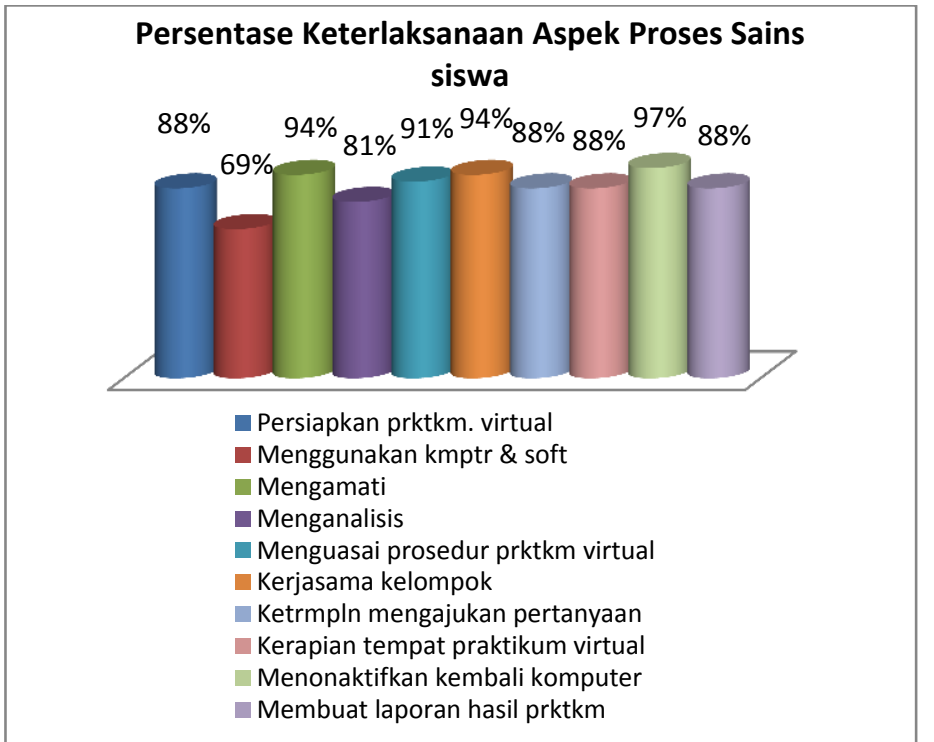

Gambar 1. Grafik keterlaksanaan aspek keterampilan preses sains siswa

Data diatas merupakan persentase rata-rata dari keseluruhan kelompok yang masing-masing per kelompok 4 sampai dengan 5 orang. Terlihat bahawa masih ada sebagian yang belum menguasai penggunaan computer dan software dimana ditunjukkan dengan nilai persentase $69 \%$, akan tetapi sebagiannya sudah mampu menggunakan computer dan menjalankan software dengan bantuan panduan secara langsung dan melalui petunjuk praktikum yang dibagikan pada setiap kelompok.

Sedankan untuk melihat keefektifan secara keseluruhan pengguanan media praktikum software proteus 8 profesional di tunjukkan dengan data perbedaan nilai preetes dan posttes dengan rata-rata $\mathrm{N}$ gain yang ditunjukkan pada table sebagai berikut :
Tabel 4. Data hasil Uji N-Gain

\begin{tabular}{ccccc}
\hline No & $\begin{array}{c}\text { Jml. } \\
\text { Siswa }\end{array}$ & $\%$ & Kriteria N-Gain & Ket. \\
\hline 1 & 22 & $67 \%$ & N-Gain $>0,70$ & Tinggi \\
2 & 11 & $33 \%$ & $\begin{array}{c}0,30 \leq \text { N-Gain } \leq \\
0,70\end{array}$ & Sedang \\
\hline
\end{tabular}

Tabel di atas menunjukkan bahwa dari 33 orang jumlah keseluruhan siswa pada pemanfaatan laboratorim virtual ditinjau dari efektivitas dengan kategori tinggi yaitu sebesar $67 \%$ atau 22 orang siswa, dan sebesar $33 \%$ atau 11 orang siswa mendapatkan pengaruh kategori sedang. Untuk lebih jelas melihat tingkat signifikan kefektifan pemanfaatan laboratorim virtual maka data titunjukkan dengan hasil uji t pairet seperti yang ditunjukkan pada table sebagai berikut :

Tabel 5. Data hasil Uji T Pairet

\begin{tabular}{cccc}
\hline Kelas & $\mathbf{T}_{\text {hitung }}$ & $\mathbf{T}_{\text {tabel }}$ & $\begin{array}{l}\text { Sig. (2- } \\
\text { tailed) }\end{array}$ \\
\hline Eksp & 18,206 & 2,036 & 0,000 \\
\hline
\end{tabular}

Uji Paired menunjukkan bahwa data yang diperoleh $\mathrm{t}$ hitung $=18,206$ dibandingkan $\mathrm{t}$ tabel $=2,036$. Kriteria pengujian $\mathrm{H}_{\mathrm{a}}$ diterima karena $\mathrm{t}_{\text {hitung }}>\mathrm{t}_{\text {table. }}$.

\section{KESIMPULAN}

Dari uaraian di atas dengan melihat data hasil penelitian yang ada maka dapat dikatakan atau ditarik kesimpulan bahwa pemanfaan laboratorium virtual berbantuan software proteus 8 professional bias dijadikan sebagai alternatif praktikum fisikan rangkaian listrik ditinjau dari efektivitas praktikum karena dapat juga membantu meningkatkan keterampilan sains siswa

\section{UCAPAN TERIMAKASIH}

Terimakasih kepada Kepala Sekolah dan guru-guru di SMA Negeri 5 Kota Bima yang sudah memberikan kesempatan dalam melakukan penelitian ini sehingga menghasilkan sebuah karya tulis.

\section{DAFTAR PUSTAKA}

[1][3] M Subhan, Eka Rahmawati, (2019). Penerapan Pembelajaran Fisika Dengan Kegiatan Laboratorium Desain Pada Konsep Kalor Untuk Meningkatkan Pemahaman Konsep dan Keterampilan Proses Sains. Gravity edu Vol. 2 No. 1 2019, Hal. 1-4

[2] Baeti S. N, Binadja A, dan Susilaningsih E, (2014). Pembelajaran Berbasis Praktikum Bervisi Sets 
Untuk Meningkatkan Keterampilan Laboratorium Dan Penguasaan Kompetensi. Jurnal Inovasi Pendidikan Kimia, Volume 8, No. 1, 2014, halaman $1260-1270$

[4] Cansiz, Sungur \& Oztekin, 2015. Exploring The Development of Science Process Skills Through History of Science Instruction. Research Gate (2015): $2735-2741$

[5] Tek \& Ruthven, 2014. Acquisition of Science Process Skills Among From 3 Students in Malyasian Smart and Mainstream Schools. Journal Of Science And Mathematics Education In S.E. Asia, Vol. 28, No. 1 (2014): 103 - 124

[6] Kusumaningsih, Y. R., C. Iswahyudi, dan E. Susanti. (2014). Pengembangan Model Laboratorium Virtual sebagai Solusi Keterbatasan Sumber Daya Pembelajaran. Prosiding Seminar Nasional Aplikasi Sains \& Teknologi (SNAST). ST AKPRIND Yogyakarta. 301-306.

[7] Jaya, H. (2012). Pengembangan Laboratorium Virtual untuk Kegiatan Praktikum dan Memfasilitasi Pendidikan Karakter di SMK. Jurnal Pendidikan Vokasi, 2(1), 5-12.

[8] Arikunto, S. (2010). Prosedur Penelitian/ Suatu Pendekatan Praktik. Jakarta : Rineka Cipta

[9] Purwanto.2011. Evaluasi Hasil Belajar. Yogyakarta: PT Pustaka Belajar.

[10] Rostina Sundayana, Statistika Penelitian Pendidikan, Bandung: Alfabeta, 2014, hal.151

[11] Budi Susetyo. (2010). Statistika untuk analisis data penelitian. Bandung: PT. Refika Aditama 